\title{
JURISPRUDENCE: DEVELOPMENT AND PRACTICAL VOCATION
}

I

FIRST AS TO THE NATURE OF JURISPRUDENCE

This age marks the renaissance of jurisprudence. One epoch in the development of sciences may with confidence be treated as passed; never again among thinking and practical men will the scientific and practical be contrasted. If one thing more than any other marks the decade that is passing, it is the domination of scientific methods in all branches of human activity except law.

This is the age of science. From now on we may expect to hear practical scholars, jurists, and men of affairs contrast the practical with the academic, or the scientific with the empirical, but henceforth whoever repeats the old phrases formerly in vogue among attorneys contrasting the theoretical and scientific with the practical will be classed among the ignorant.

Science accompanies the farmer in his sowing and his reaping, the laborer at his task, the mechanic operates according to laws; indeed science is everywhere predominant except among lawyers, and at bar associations.

Just what is meant by science? No doubt there are as many definitions as there are viewpoints, but after all there may be seen through all of them and as the sum of all this simple idea, the systematic research for and exposition of truth. The quest may be as to mental operations, normal principles, physics, ethics, social relations, business or war, but through it all science seeks, finds and expounds. Science simplifies and makes appreciable all it touches. Research and exposition are the processes of scientific system; harmony and simplicity the result.

From two sources widely different the writer encountered the expressions substantially as follows: "If science exists there must be a philosophy of science, for there must be a reason for the reliability of knowledge." The other: "If there is a science of law it must have a basis. . . . I presume this is what is meant by the philosophy of jurisprudence . . . unless there is such a philosophy deeper down than the science, then the science is falsely so called." 
Here is a suggestion that there is a difference between the philosophy of jurisprudence and the science of jurisprudence.

There is an underlying philosophy constituting the merely spiritual content of the science, there is also the formal expression and the material matter which constitutes the generally recognized and visible matter of the subject: in our case the institutions, elements, or norms of principle and rules of law. Encompassing all of these is the science, or, as we say, the jurisprudence.

Jurisprudence, then, is of the form; philosophy is of the substance, though not all of the substance, the palpable things mentioned being also of the substance, and indeed they constitute the material body which we apprehend and expound and apply as the law.

The distinctions here intimated, rather than explained, had been made in the period of the classical jurists and these philosophers and logicians saw and expressed clearly that science is the instrument or means of giving formal expression to facts while philosophy determined the truth of alleged facts. In this sense philosophy is creative; science is constructive.

Of course in practical operation these elements are so associated that the distinction is seldom made and in writing it is seldom consistently observed. Nevertheless English jurists have kept in mind that the soul or spirit of the law was a part and a very substantial part of the law.

The creation of a system properly designated as scientific requires: (a) the expression of all the component elements or constituents of the whole subject; (b) a classification of these in accordance with an appreciable principle which constitutes a guide to the arrangement. The result is necessarily a formal and visible picture displaying the whole as an articulate or coördinate body in which each part is seen in relation to the whole and the parts appear in reciprocal relation to each otherthis is a system. There is no isolation; there is organization.

In a system of law subjected to such treatment there can be no real conflicts as to identical matter, though in a body of law composed of a national jurisdiction with many state jurisdictions, there may be contrasts; these by the system must needs be made apparent and being apparent and subjected to the light of the underlying philosophy or reason, where harmony is desirable the better reason is likely soon to prevail. 
The distinction between harmony and unity or identity must in dealing with the law of distinct states be kept in mind. Absolute identity of law throughout the states is not desirable, discord where conditions are identical is deplorable.

In a recent number of the Harvard Law Review, Professor Wigmore makes a plea for the establishment in the schools of the same thing the writer has been advocating for the last twenty years. Professor Wigmore expresses his idea in the dead language of the Greek philosopher and handicaps it with the necessity for the introduction of the old terminology. "The Plea for the Science of Nomo-thetics," translated into modern English as "A Plea for a Fixed Nomenclature and a Formal Classification," ought to receive instant and hearty acceptance, but the necessity or the utility of attempting the introduction of a new nomenclature does not seem clear.

The ideas alluded to by Professor Wigmore are very simple and have been expressed in all the languages in which the continuous progress of occidental civilization has been expressed.

Jurisprudence as the equivalent of the science of law sounds as well as Nomology or nomo-logy.

But it is not the weak points of Professor Wigmore's argument which should be emphasized but the strong ones. No practical shade of difference exists between the Greek Nomology and the anglicized latin Jurisprudence, if the philosophical element abovie referred to is embraced within the content, as, in truth, it must. A science so called would be mere dead and dry formalism without the spirit of philosophy showing the origin of and reason for its constituent truths.

A given mass of rules and principles is a mere mass lacking entirely the harmony and unity and simplicity of a body until science displays the mass as a system complete, coherent and coördinate.

It is precisely at this point that American law is breaking down. The reasons it is drifting into confusion are (a) that the philosophy of the inner unity of all law is lost sight of and (b) the science which gives it visible form as an integral system is ignored.

In the controversy over methods, the higher and more important matter of the system has been forgotten.

If law is to be handled scientifically the paramount methods of science must be invoked.

\footnotetext{
${ }^{1}$ Harvard Law Rev., vol. XXVIII, p. I.
} 
One of the philosophical writers mentioned above writes, "The philosophy of science uses the formal sciences as the organ of thought and supplies to the science of concrete phenomena the method of establishing truth," . . . elsewhere, "There are always two factors in establishing scientific truth . . . first, sense and experience, and second, method. By method we mean the function of handling the material, viz., identifying samenesses and differences, comparing phenomena, i. e., classifying and contrasting them; tracing the succession of cause and effect, and arranging the truths thus established into an harmonious system."

\section{II}

THE DEVELOPMENT OF JURISPRUDENCE

Enough has already been said to suggest that a philosophy of law had been developed by the Greek philosophers. The ancient codes of course attest the long-established rules of law applicable to daily life of the people.

The philosophers carried their inquiries deeper. They discovered the "norms" and established a "logy" pertaining to the social order with, of course, a vernacular nomenclature, Nomology-Nomo Komios, etc. They carried their prognostications so far as to suggest the modern idea of nomocracy-or a government of law. While here there is much of the philosophy, there is little of the formal science as applied to the exposition of a specific body of law. The Greek did, however, furnish the principle upon which a little later there was to be built the first formal outlines upon which all modern systems of jurisprudence have been erected.

The philosophy of the world was given the form of a science in the first great university of the world. The philosophy of Greece (or rather Alexandria) has ever since ruled the world, but it was left for the genius of the Roman with a wider knowledge and richer material to create a broad comprehensive system upon foundations which have not been moved.

Whoever will examine carefully into the foundations and elemental norms of the British system after its establishment on "the rock which has not been submerged" will discover at the base a principle which found its first expression in the utopian dreams of the classical philosopher.

To the Aristotelian publicist the term justice implies the case of those who have laws (nomoi) to which they are subject. In 
this view the terms justice and the law (nomos) connote the same essential idea. ${ }^{2}$

This idealism took the form of personifying the law under the title King Nomos (nomocracy) or as the modern expression goes, the sovereignty of the law. ${ }^{3}$ The common sense or reason of the community, custom, mores, nomos are of the same idea.

It is a far cry from the protest of Thersites to the theories of the Greek politicians, dreary centuries elapse before the principle of due process of law became the chief stone in the corner "the rock that has not been submerged."

Modern law began with Magna Carta when no man could be affected in his rights save by due process of law; jurisprudence achieved its greatest triumph when political theories combined with practical effort in the establishment of a government of law. Through the struggle of the ages the theories of the jurists begot the crowning triumph of civilization, justice according to law.

The perpetuation of the system depends upon the recognition of the manner of its origin and application of the principles of its existence.

Just when modern formal jurisprudence began, and by whom it was given its new impulse, will, of course, be matters of dispute: whether to Irnerius, as Maitland believes, is due the credit of establishing this human science alongside of theology, or Bartolus, as Sohm affirms, or to Donellus, as Professor Pound seems to declare, is likely to be a subject of dispute. Who is the founder of the modern science of jurisprudence turns somewhat on the individual estimate of the nature and influence of an event or effort, and the meaning of jurisprudence as denoting more or less of philosophy and formal classification.

Indeed it is quite possible that there may be those who would affirm that the Alpha and Omega of jurisprudence combined when alphabetical arrangement took the place of classification as a means of expounding law, or as they would say, when the practical put aside the theoretical.

However this may be, the beginning of a pure science of jurisprudence, i. e., a system of exposition based on a principle

'Smith, Crowned Essay. The State Am. Philosophical Soc., vol. XXXIV, p. 298.

"Id., p. 316. "Nomos is King and Reason his Counsellor." 43 Am. Law Rev., 843. It is here that Austin's theories of Sovereignty breaks with the British Constitution. 
of classification and executed with strict observance of wellconsidered and rational methods, has been traced to a much earlier period than one might be led, from a reading of Gibbons, Chapter 44, to accept as the beginning of scientific jurisprudence.

Upon the subject of the creation of a jurisprudence such as is contemplated by modern scholars, Professor Sohm has this to say:

"The same Aelius whom we have just mentioned, surnamed 'Catus,' 'the cunning' (Sextus Aelius Paetus Catus, Consul I98 B. C.), had already composed a work, called the 'commentaria tripertita,' in which, not content with making a mere collection of formulae, he offered a commentary on the Twelve Tables and the formulae for actions and juristic acts. These 'commentaria' are, it is true, nothing more than explanatory or exegetic notes, but still they represent the first attempt to set forth the pontifical jus civile in a literary form; they are the first law book, the 'cradle of legal literature.' From this time onward the technical knowledge of law passed more and more out of the hands of the pontifices and became an ingredient in national culture. At the same time the influence of Greek literature, and, more especially, the scientific methods of the Stoic philosophy, operated as a powerful and ennobling stimulant. The idea now suggested itself of casting the hard materials of law into a suitable artistic form. Thus, at an early date, we find M. Porcius Cato, the younger (who died 152 B. C.), making a conscious attempt to work out general principles of law. (regulae juris), i. e., to trace in the raw material of legal rules, as presented by history, the underlying legal idea, to shape the statue from the rough block of marble. The' most distinguished of all these 'veteres' was $Q u$. Mucius Scaevola, the younger, pontifex maximus. About roo B. C. he wrote his great treatise on the jus civile, in eighteen books, a work of wide and enduring fame. In this treatise the positive private law was, for the first time, set forth in systematic order, i. e., arranged and classified according to the nature of the subjects dealt with. Scaevola's system remained the foundation for the labours of his successors. He abandoned the traditional legal arrangement of simply following the words of statutes or of the formulae relating to procedure or juristic acts, and adding explanatory notes. Nor did he confine himself, like earlier writers, to the discussion of isolated cases or questions of law. He arranged his work according to the subject-matter with which the several rules of lawe were concerned, and in which they were, so to speak, focussed. He was the first to determine, in clear outline, the nature of the legal institutions (will, legacy, guardianship, partnership, sale, hiring, etc.), and their 
various kinds (genera). He made the first attempt to set out general legal conceptions, i. e., those elements which go to make up the checkered and, to all appearances, boundless mass of concrete facts. This is the secret of the great significance and enormous success of his work. His achievements rendered it possible, for the first time, to survey private law arising as a whole beyond all the complexities of detail. A mere knowledge of law was beginning to develop into a legal science."'4

The development of jurisprudence at the hands of the Romans may be passed over with the mere mention of Gaius and Justinian, as marking the stages of a progressive improvement. With the main portions of the Corpus Juris we are not at present interested, excepting as the basis of the work of later civilians.

In the creation of a modern jurisprudence the work of the Italian glossators constitutes the foundation of the edifice later erected by the commentators.

The central figure in this effort is Irnerius. The true importance of his work is attested by no less authority than Professor Maitland.

Professor Maitland says:

"A history of civilization would be miserably imperfect if it took no account of the first new birth of Roman law in the Bologna of Innerius. Indeed there are who think that no later movement-not the Renaissance, not the Reformation-draws the stronger line across the annals of mankind than that which is drawn about the year IIOO when a human science won a place beside theology."

Why is the methodical exposition of law (for that is the highest power to which the work of the glossators can be brought) spoken of as a human science and accorded such an exalted place in the development of civilization?

It marks the effort to place human right or justice upon the foundation of reason and philosophy, and just so far as law is made definite and justice is removed from individual caprice and afforded a standard in common reason translated into common law, so far is there civilization.

The work of the commentators was vitally different and whether the task of bringing to light the historical, philosophical and economical basis or reason for law or the scientific task of

'Sohm's Inst., pp. 90-I.

- English Law and the Renaissance, Maitland. 
giving unity, harmony and order is the greater, will of course depend upon the time and point of view.

Professor Sohm gives this estimate of the character and value of the work of the commentator:

"The task, which had devolved upon Roman jurisprudence, and which it had (through the commentators) now solved, had been a two-fold one:

"First, to consolidate into a uniform system the lawe that lay stored up in all the manifold sources, from the time of the Truelve Tables downwards;

"Secondly, to develop, in a scientific form, the abundance of matter which these sources of law contained. . . . The problem here was to discover the true nature of the dealings themselves, to trace the unexpressed and unconscious intention underlying all such dealings, and having traced it, to put it into words, to clothe it in a form in which definiteness and lucidity should be coupled with a degree of comprehensiveness sufficient to bring out the broad general principle governing, not merely a large number of cases, but positively all cases, including those which were peculiar and exceptional. SUCH A PROBLEM TOUCHED THE CREATION RATHER THAN THE APPLICATION OF LAW. But it was precisely in performing a task of this kind that the genius of Roman jurisprudence came most strikingly into play. In spite of its innate dialectic strength and discipline, it had but few dogmatic interests in the modern scientific sense of the term."

Bearing in mind that it is this modernized civil law and not the ancient Roman law which was received throughout modern Europe, we may note the one paramount effect of the labors of truly scientific commentators, that is, the constant expansion and adaptation of the common law, the jus gentium, by the process of reason.

This is, in truth, the great phenomenon of jurisprudence, the domination and permanency of principles and their adaptation to ever changing conditions.

The effect of the jurist-made law on legislation is stated by Sohm as follows:

'In interpreting the 'letter' of the statutes there was a growing tendency, all reservations notwithstanding, to give effect to the ideas of the new common law. The victory of the common law was thus assured. Its strength lay in the fact that it was founded on scientific principles, and

\footnotetext{
'Sohm's Inst., pp. ror-2.
} 
its signal practical triumph was due to the special labrors of the Commentators. Just as the growth of a common national art and literature tended to reduce the differences of language and national character in Italy, so the success of the new scientific movement tended to reduce the existing differences in the law and to bring unity into the legal ideas and habits of the people.

". - the fact that the law taught by the Commentators ever became the actual common law of the country was the outcome of this very theory that the statutes should not be interpreted in the light of the statute law itself, but in the light of the common law.

"... The foundations of modern Continental jurisprudence were thus laid."?

Whatever of jurisprudence England has had has been based professedly upon the science of the Roman and civilian jurists; another origin has been ascribed to the law of England but that is a matter foreign to this article. The classification of Gaius has been adopted and adapted with more or less skill and with conscious imitation. Whether owing to the simplicity of the subject, the adaptability of the laws or the power and skill of the English jurists, their labors developed at one period a formal exposition of the whole body of English law which for fundamentalness, clearness and order has never been surpassed.

That the results worked out by Hale, Dr. Wood and Blackstone really deserve so high an estimate is attested by the jurists whose labors in this field have enjoyed a high reputation among jurists in the field of scientific legal exposition.

Dr. Heinrich Brunner, who for forty years has been in the first rank of German jurists, wrote of Blackstone's effort as follows:

"It may be boldly asserted that none of the modern systems of laze can show such a completed and rounded exposition, on the whole, as the English system possesses in Blackstone."

Chan-Toon (barrister of the Middle Temple), author of a Treatise on Jurisprudence (I889), says:

"The origin of classifying departments of law may be traced to the crude arrangement of the Twelve Tables, and to the institutional writers, who afterwards rearranged the laws contained in the first code of the Romans in

'Sohm's Inst., pp. 143-4-6. 
their commentaries. Gaius in his institutes represents the analytical method of classification as conceived by the classical jurists. . .

The main divisions of law as perceived by Gaius and the other institutional writers were implicitly followed by the civilians, and are still adopted with varying qualifications by modern jurists.

There has been a tendency to find too much fault with Blackstone. It must be acknowledged that he is the only writer who has attempted, with substantial results, the herculean task of writing the entire English Law. . . .

Comparing the classifications of the Roman jurists and Blackstone's, we notice an improvement in the latter."

That the principles upon which the classical jurists based their system have been so widely adopted has been attested by many jurists.

The following will suffice our present purpose:

"The jurist Gaius, who died after I80 A. D., and whose institutional treatise was adopted as a model by all subsequent zeriters of legal textbooks, is the last in whom the opposition between the schools is represented."

"As regards Gaius himself, it is important to remember that whatever reputation he acquired in later days and however enduring has been his fame as the model for all systematic treatise-zeriters on law, in his own time he was only a private lecturer."

Those who have studied the origin and progress of the system of law originally established in this country need no argument as to the constructive and unifying power of the labors of the great English commentator, but since in the last halfcentury the regard for Blackstone has been allowed to wane and the use of the institutional system of which his book was the highest exponent has to a large extent been discontinued, it may not be amiss to show by the highest expert opinion the constructive and unifying influence of Blackstone's Commentaries in moulding and fashioning the law of this country.

Maitland, in a lecture at Oxford, published under the title "English Law and the Renaissance," graphically flashes the picture and points a tacit admonition:

"James Kent, aged-fifteen, found a copy, and (to use his own words) was inspired with awe; John Marshall

- Sohm's Inst., p. 98.

'Abdy \& Walker's Gaius, Cambridge, Eng., I87o, Int. VII. 
found a copy in his father's library; AND THE COMMON LaW Went stratght to the Pactfic.

"A hundred legislatures-little more or less-are now building on that foundation; on the rock that was not submerged. We will not say this boastfully. Far from it. . . . If unity of law-such unity as there has beendisappears, much else that we treasure will disappear also, and (to speak frankly), unity of law is precarious." 10

The lesson drawn from this and the experience of the ages is this. That at the center or bottom of all systems which have emerged from the condition of mere arbitrary power there is the unifying principle of natural reason (call it jus gentium or common law), and unless stifled it will prevail and will dominate all forms of law.

\section{III}

THE PRACTICAL VOCATION OF JURISPRUDENCE

In considering the practical vocation of jurisprudence it is assumed that we are regarding the subject from the point of its expository function rather than from an explanation of the creative function which has through all time been a very marked feature of the purely philosophic or academic phase of the science, for it must not be overlooked that a very large proportion of law is jurist-made rather than judge-made.

It is to be remarked that jurists and judges always profess merely to declare and perhaps it is true that both the judges and the jurists are chanticleers rather than authors of light, merely declaring the advent of what other causes bring to pass. ${ }^{11}$

At this point it is necessary to point out the special fields in which jurisprudence operates.

The first of these is purely constructive, consisting entirely of making the law knowable. This is accomplished by means of codification, i. e., exposition under legal sanction and formal exposition by means of books, comprehensive or topical, but always scientifically classified. Every effort to make the law knowable and reduce it to a system is an effort in jurisprudence.

Alphabetical and other unclassified discourses always tend to disintegrate and throw the law into confusion.

\footnotetext{
${ }^{10}$ Maitland, English Law and the Renaissance, pp. 32-3.

"See Le Baron B. Colt, Law and Reasonableness. Am. Bar Ass'n Rep., vol. XXVI (I903), p. 341 .
} 
The experience of the world proves that the fundamental primary and ultimate book, establishing and preserving order and harmony in the law, in a word creating a system, is the so-called institutional treatise.

Without such a book, generally accepted, there can be no jurisprudence worthy of the name. With such a book scientifically classifying the contents of the law, and bringing clearly to the foreground the permanent institutions, the dominating principles, the main rules and leading and ruling precedents; accepted and sanctioned as it should be by the legal profession, no body of law can fall into confusion. Such a system tends to uniformity, consistency and harmony.

The first effort in any comprehensive reformation of American law must be the creation of a system of classification expressed in an institutional commentary. Until this is done all other efforts will be transitory and barren of results.

Grueber, in a review of Holtzendorff's encyclopedia, ${ }^{12}$ says:

"In order to codify existing law it must have previously existed in the form of a scientific system, i. e., in the form of rules which are . . . arranged according to certain leading conceptions."

The first effort of every codifier is of course classification. Mr. Justice Holmes had the perception that saw that the necessity for codification was almost met by a thorough and scientific classification.

When our jurists and legislators see this, they will bend their energies to a coöperative effort to produce a real classification of existing law.

The next field for the efficient practical application of jurisprudence is in the field of legislation. It is gratifying to observe that this is already engaging the attention of the legislatures in some states and that bar associations are coopperating. It is to be regretted that nowhere has any appreciation been shown of the fundamental scientific truth that a system must be first created before the work of compelling legislation to conform to order and consistency.

That jurisprudence should dominate legal education is so obvious that no one will argue against it.

That jurisprudence, properly so-called, has no place in any of our larger colleges of law, as a means of imparting a broad

\footnotetext{
23 I Law Quarterly Review, p. 62.
} 
comprehension of the law as a system and a clear apprehension of the reciprocal and coördinating relation of the parts, is a fact which most of those teaching in the schools will admit.

That scientific methods of imparting and acquiring a knowledge of the origin and development of the rules and principles and their illustration by precedents are in use in all schools may be admitted and that these methods are elements in any system of jurisprudence may also be admitted. This does not, however, by any means, involve a contradiction of the second proposition above stated.

The importance of making jurisprudence the dominating element in even the vocational or professional law school cannot be over-estimated. By no other means can a comprehensive, complete and fundamental conception of the law or of any part of the law be given. In no other way can a uniform and harmonious conception be given to the whole body of lawyers.

No codification or systematic restatement of law can maintain the harmony of the law unless the legal profession is educated in accordance with its fundamental concepts and are familiar with its classification and why such classification prevails. The law schools educating the youth who to-morrow will be the lawyer and shortly the magistrate have the great opportunity and the corresponding obligation.

In the last seventy-five years the law schools have increased from about ten to over one hundred and ten. The lawyers have increased from a few thousand to over one hundred thousand.

But in the meantime, what of the law? Is our law progressing satisfactorily either in substance or in form? Is the profession maintaining its high place relatively in the esteem and regard of the people? Is it performing its high functions with close approximation to the high ideals its teachers are so prone to dwell upon on high occasions? Are the law schools performing to the highest degree their obligation to furnish the most scientific education?

The occasion for argument over either of these questions is long since past; an opinion as to each will perhaps impress the apathetic. Among the latest expressions of the late Judge Hornblower is this: "The present condition of the law is little short of appalling."

At the meeting of the American Bar Association at Montreal, ex-President Taft dwelt upon the waning prestige of the bar. 
As the third question, passing by familiar admonitions and pleas for the introduction of jurisprudence in the schools, attention is directed to arguments from different sources.

In an official memorial issued by Johns Hopkins University is the following:

" $A$ Law School of High Grade.-There is need for the establishment of a School of Jurisprudence which will furnish instruction in the higher branches of the law and opportunity for scientific research-historical, comparative and critical.

There is at present no such institution in the country, all other law schools being wholly vocational or professional in character. The opportunity is thus offered to inaugurate in the field of law, public and private, the same scientific methods that have given such distinction to the Johns Hopkins Medical School in the field of medicine."

That Dean Langdell had in the beginning of his efforts the conception of a system and the utility of giving this system expression in a comprehensive form appears clearly in the introduction to his first book of cases. He writes:

"Law considered as a science consists of certain principles or doctrines. To have such a mastery of these as to be able to apply them with consistent facility and certainty to the ever-tangled skein of human affairs is what constitutes a true lawyer. . . . Moreover the number of fundamental legal doctrines is much less than is commonly supposed; the many different guises in which the same doctrine is constantly making its appearance and the great extent to which legal treatises are a repetition of each other being the cause of much misapprehension. IF THESE DOCTRINES COULD BE SO CLASSIFIED AND ARRANGED THAT EACH SHOULD BE FOUND IN ITS PROPER PLACE AND NO WHERE ELSE THEY WOULD CEASE TO BE FORMIDABLE FROM THEIR NUMBER."

That his whole effort is one of classification is perfectly clear. That each topic is but a part of a coördinated whole was likewise plainly stated.

The arguments in favor of the scientifically arranged treatise as an outline presenting the elements of the law and all the elements, i. e., the institutions as well as the principles, doctrines, rules and illustrations of application, are mere corollaries.

That the case method of instruction developed upon one of the lines indicated, while the classification of the whole sub- 
ject of study, viz., the body of American Law, was not kept up, is of course now well understood. The reason is not difficult to understand and has recently been very clearly explained.

The neglect of the system as a system, that is, classified institutes, in the so-called textbook schools resulted from the same causes but was and is less justifiable. Topical textbooks and topical lectures can no more supply the deficiency than can carefully selected cases on leading subjects or topics, and the latter, given time and competent instructors, are more valuable as means of teaching the origin, reasons and application of principles, doctrines and rules.

If a choice were necessary as between the two methods, few would find difficulty in making it, but no such choice is necessary and in actual experience is not made or advised by any one anywhere.

The weakness of both methods is that they dwarf, if they do not entirely ignore, an essential part of a broad and comprehensive legal education. The result as shown by two generations of experience is that the law is becoming confused and uncertain, that it is losing its quality of fixedness or due process, as a natural consequence the profession is losing its relative prestige. The cause of all the trouble and complaint is the lack of a genuinely scientific legal system. ${ }^{13}$ "This," says Professor Redlich, "is primarily due to the fact that, up to the present, legal science has not kept pace with the remarkable wealth of the common law in legal substance."14 Here it is that legal education has failed of performing its highest function.

The condition and the remedy are concisely stated by Dr. Redlich in the report referred to.

"Herein we find the strength, but herein also the weaknesses of the case method. These weaknesses, to sum up the writer's opinion in a word, lie on the scientific side of American legal instruction in its present form. In this connection we may distinguish between, first, the influence exerted by the case method upon the scientific comprehension of law by the students, that is to say, upon legal instruction proper, and secondly, its reaction upon the scientific elaboration of law in general, that important function of law faculties which we must consider apart from their purely pedagogic aims.

\footnotetext{
${ }^{23}$ Pound, Taught Law; 37 Am. Bar Ass'n Rep., p. 975.

${ }^{14}$ Report of Dr. Redlich on the Case Method. Bulletin No. VIII, Carnegie Foundation for Teaching, p. 61 .
} 
"With respect to the first point, it seems to me that the following consideration is of some importance. It is characteristic of the case method that where it has thoroughly established itself, legal education has assumed the form of instruction almost exclusively through analysis of separate cases. The result of this is that the students never obtain a general picture of the law as a whole, not even a picture that includes only its main features. This is, in my opinion, however, just as important for the study of Anglo-American law as for the codified continental systems, and is a task which should also be accomplished by the law courses in the universities. To this end, the following seems to me above all things requisite:

"First, as an introduction to the entire curriculum, care should be taken to introduce to the student, in elementary fashion, the fundamental concepts and legal ideas that are common to all divisions of the common law. Or, to express it in a word common in European pedagogy, the beginners in American law schools should be given a legal Propädeutik, or preparatory course, which in a simple yet scientific manner shall set forth the elements of the common law, shall furnish, that is to say, a comprehensive view of the permanent underlying concepts, forms, and principles, not forgetting the elementary postulates of law and legal relationships in general. The more rigorously casuistic the case method of instruction which then follows necessarily has to be, the more important it seems to me it is to make clear to the students, at the very beginning certain fundamental facts and guideposts of the law which are removed from all casuistry and theoretical controversy. Only in this way will their future studies rest upon a solid and scientifically grounded foundation."

The one-sidedness, the narrowness and shortsightedness of ignoring or slighting the one element essential to a scientific system and exaggerating another, even of equal value, are also strongly stated by him.

"I have, however, in my positive suggestions also pointed to the necessity of supplementing these analytic exercises, both at the beginning and at the conclusion of the course, by scientific, systematic lectures, and finally I have also referred to the fact that a more extensive growth of scientific legal literature in the United States may be expected with full certainty from the forces now at work, and fortunately so, for the reason that it seems essential to further progress. Therefore I do not hesitate to say again expressly that the unqualified rejection of the lecture from the curriculum of the university law schools, and the extraordinary slighting of literary aids to the 
study of law, seems an error and a prejudice which has its origin in an undoubted exaggeration of the value of the analytic method in and for itself, and possibly also in an exaggeration of the value in scientific instruction of 'method' in general." 15

The great problems which lie before us, the solution of which, for the United States as well as for the world, it is the practical vocation of jurists by means of the application of jurisprudence to work out, are thus stated by Dr. Redlich:

\begin{abstract}
"Herewith, I believe, however, that the two great problems are revealed whose solution devolves upon American jurisprudence: the creation of a scientific system of the common law, and a reform of the common law in the direction of that movement which is becoming more and more pronounced among the people of the United States in favor of a simplification, a greater efficiency and improvement, of substantive law as well as of civil and criminal procedure."
\end{abstract}

The vocation of jurisprudence is plain: the practical utility of that vocation has been demonstrated by many examples. The question before the profession and all its branches, teachers of law, judges, practitioners and legislators is simply this: will they coöperate in an effort to reëstablish jurisprudence as a vital part of the law.

Efficient effort must not be individual, sectional, or, as we may say, sectarian but must be real coöperation in an effort to bring to bear upon the problem the best brain power of the nation.

The ideal must not be to create a system for one school but a system of education which shall faithfully portray the lineaments, the framework, the vital forces, the practical functions of the actual corpus juris existing everywhere alike.

Let there be generous rivalry as to methods but there must be cordial coöperation to create the system and give its outlines substance, and principles the form of a scientifically classified system.

Let me close with the sentiment of the late Judge Dillon:

"There is here room and need for all. The institutional writer, the law teacher, the philosophic student, the scientific jurist, the experienced lawyer, the learned judge, the

\footnotetext{
${ }^{25}$ Id., p. 54.
} 
practical legislator, has each his place. They are not repellant and antagonistic agencies, but allies and colaborers in the noblest work that can engage the attention and draw forth and exemplify the highest powers of the human intellect. Toward the realization of this ideal let us press on with generous ardor."

NEW YORK.

James Dewitt Andrews. 